\title{
The Role of Ecological Diversity and Identity for Sustainable Development of Islands
}

\author{
Sun-Kee Hong \\ Institution for Marine \& Island Cultures, Mokpo National University \\ landskhong@gmail.com \\ Publication Information: \\ Received 23 March 2019, Accepted 25 May 2019, Available online 1 June 2019 \\ DOI: 10.21463/jmic.2019.08.1.04
}

\begin{abstract}
A multidisciplinary research method is essential to get a handle on the various features of the island. First of all, it is required to understand the basis of living environment such as biological resources and topography in land and ocean, and the supply of safe drinking water. Also, the physical feature of accessibility, that is, distance from the mainland and how to move, becomes an essential element. Since life on the islands almost entirely depends on natural resources, the ecological health of the surrounding marine ecosystem is also closely linked to economic activity. Since life on the islands depends very much on mobility and resources, the sustainable use and conservation are necessary within the limited island space, and this management system has been maintained by the community of residents. With the recent increase in island tourists, environmental problems such as marine pollution have arisen, along with concerns over its environmental carrying capacity. This paper discusses whether there is any way to seek sustainable development while maintaining the island's diverse identity and biological and ecological diversity.
\end{abstract}

\section{Keywords}

island identity, sustainability, ecological diversity, biodiversity, island industry

\section{Introduction}

Looking from a broad perspective, the island ecosystem has different structure and function from the land ecosystem, and the environment that affects ecosystem is very different. Land ecosystems may be primarily affected by other ecosystems on the adjacent land (Huston, 2014), but the island ecosystem is primarily affected by the water body, the sea. However, when looking at various landscape elements in the island, we can see that the marine ecosystem (including the coastal ecosystem) as well as the rural, forest, wetland and even urban ecological characteristics are 
mixed and complexly connected together (Grydehøj, 2015). Therefore, the island is just the place to expand ecosystem by networking with the sea that is seen only from the viewpoint of land. In particular, the shape and the coastal ecosystem structure of the island forms differently according to or in connection with the geographical space such as the West Sea, the Southwest Sea, the South Sea and the East Sea, and at the same time, the direct or indirect effects of human activities on the island works differently according to the feature of sea area, so the island is a very important place to observe the cultural identity as well as the ecological process (Hong, 2011a).

I have been working on several points of view while studying islands. The first is 'diversity'. I have learned that there were very diverse spectrum of islands in nature, culture, history and economy, while going around islands of countries in Asia and Europe, as well as in Korea (Baldacchino, 2019). Especially, as an ecologist, I have well recognized that many academic studies that are the basis of modern ecological theory, including biological evolution theory have taken place on the island, have been conducted in islands. The second is 'complexity'. I think it can be complex because it is diverse. The island ecosystem has terrestrial ecosystem as well as various transition areas linked to the sea, including coastal and tidal flat ecosystem. Human activities are being actively carried out not only on land but also in transition areas. These human activities on both sides of the land and sea have complicated the island ecosystem. The third is 'identity' (Campbell, 2009, Kakazu, 2019). The long-preserved terrestrial ecosystem is very stable and has a unique biota. We call this phenomenon climax. If the island has also been isolated for a long time and its ecosystem has been well preserved, it's a very unique biota is revealed. This island biodiversity is determined by its climate, geology and water quality and it is also importance issues for designing island policy (Table 1).

Table 1. Key features and issues in island areas (Shim, 2015)

\begin{tabular}{|c|c|c|}
\hline Item & Key features & Key issues \\
\hline nature, ecosystem & $\begin{array}{l}\text { - Unique natural resources and landscape } \\
\text { - Sensitive natural ecosystem } \\
\text { - Vulnerable management system for the natural } \\
\text { ecosystem }\end{array}$ & $\begin{array}{l}\text { - Sustainable use of natural ecosystem and landscape } \\
\text { resources } \\
\text { - Development of management system for the natural } \\
\text { ecosystem and landscape } \\
\text { - Encouraging eco-friendly island tourism }\end{array}$ \\
\hline society, culture & $\begin{array}{l}\text { - Unique cultural resources } \\
\text { - Depopulation and ageing } \\
\text { - Lack of human resources and infrastructure }\end{array}$ & $\begin{array}{l}\text { - To maintain charm and island-like cultural resource } \\
\text { - To improve domiciliation and to maintain population } \\
\text { - To strengthen community capabilities }\end{array}$ \\
\hline economic structure & $\begin{array}{l}\text { - Traditional industrial structure centered on } \\
\text { agriculture and fisheries } \\
\text { - Vulnerable and simple economy } \\
\text { - Weak industrial development structure }\end{array}$ & $\begin{array}{l}\text { - To increase value-added of agriculture and fisheries, } 6^{\text {th }} \\
\text { industrialization } \\
\text { - To develop tourism business linked to traditional } \\
\text { industries } \\
\text { - Balance and trade-off between tourism and traditional } \\
\text { industries }\end{array}$ \\
\hline $\begin{array}{l}\text { tourism, development, } \\
\text { environment }\end{array}$ & $\begin{array}{l}\text { Various development controls and lack of } \\
\text { available land } \\
\text { - Market instability (seasonality, weekend } \\
\text { concentration) } \\
\text { - High cost structure of tourism development }\end{array}$ & $\begin{array}{l}\text { - Strategies to make tourism attraction through creative } \\
\text { use of island resources } \\
\text { - Selective private investment } \\
\text { - Continuous improvement of accessibility, and creating } \\
\text { markets }\end{array}$ \\
\hline
\end{tabular}


Islanders have been living on various island resources since they had settled on the island first. They got a handle on the characteristics of the soil to cultivate, and performed fishery according to the features of the sea. As such, the characteristics of the island and surrounding sea environment served as a very important facilitator for the development of the island's cultural diversity. The agenda, "Strengthening Bio-cultural Diversity and Traditional Ecological Knowledge in Asia-Pacific Island Regions" (IUCN Resolution 5.115), which I submitted to the World Conservation Congress (WCC) held at Jeju in 2012 and was adopted as a resolution, is a result of paying the cosmopolitan's attention to 'islandness' (Hong et al., 2014).

Finally, the author's interest is in the island's 'sustainability' (Kelman, 2006). As the islanders have to live on a limited area with limited resources and environment, their lives and nature conservation is like two faces of the same coin. Resources are needed to live on an island, and the resource depletion decays the island's function on settlement environment (Rapport, 2006). Thus, the island is a suitable place to develop a model that can test and implement 'sustainability'. The island is a very vulnerable to climate change. Therefore, there are many things to incorporate high-tech technologies such as new clean energy, new industry and new residential environment like passive houses. Sustainable development is accompanied by the development of science and technology. The islands of our country need to change and join in the future development process in the era of global environmental change.

\section{Biodiversity and ecosystem of island}

There is a saying, "The forest is the ocean's sweetheart." This phrase was well known earlier by "The Forest is the Ocean's Sweetheart (森は海の恋人)” written by a Japanese aquaculturist and essayist, Shigeatsu Hatakeyama (2006), and is quite consistent with the captain's natural guidance. In Europe and North America, forests are often created with sea plants to increase the abundance of fish farms and to improve biodiversity in the ocean. Laminariaceous large-scale algae known as kelp are commonly used. In fact, algae are not the only contributors to the increase in marine biological resources. There are many cases where the forests and trees on land provide habitats and spawning grounds (Botsford et al., 1997, Caldeira and Wickett, 2003). The fishing community in Koshikijima, Kagoshima, which was designated as Japan's quasi-national park in 2017, holds an interesting event. When the cut and bundled branches in the forest sink into the sea with a heap of soil, the squid spawns on the leaves. In other words, the trees on the land can also serve as spawning grounds and habitats for fish (Hong and Kim, 2007). The fishing community members plant trees on a regular basis. They are fishermen who plant trees. In Japan, the fisherman forest is included in the classification of the cultural value of forests. As there are high mountains, rivers and streams developed towards the coast in Japan, various river forests, estuary forests and coastal forests have been developed.

Traditionally, these forests have helped inhabitation of fishes and served as spawning grounds for fishes, and was defined as the term of 'fisherman forests' (Hong, 2010). There are 10 fisherman's forests in Korea including tide-water control forest in Mulgeon-ri, Namhae-gun, but there is a concern that the name of 'fisherman's forest(Eoburim in Korean)' may be designated as the type of coastal protection forest during Japanese Colonial Period, and so the name is required to be changed based on accurate research. Japan has been planting coastal areas for many years because of frequent natural disasters such as tsunamis and typhoons. These remains in various parts of the country, and hundreds of meters of tide-water control forest and windbreak forest reportedly prevented tsunami to some extent when a tsunami caused 
by 2011 Tohoku Earthquake came. The tide-water control forest and windbreak forest remaining on the island coasts of Korea serve as cultural assets, but do not play as a role in protecting the ecological environment. This is because a considerable area has been changed to an agricultural area, a village district or a beach (Hong et al., 2010). As there are no big disasters like tsunami, the windbreak forests in coastal areas are almost gone. In order for the forest to be a true 'ocean's sweetheart' that collects and spawns fishes and purifies water, the coastal area management should be reorganized, and ecological methods should be used to recreate ocean and coastal forests.

Many islands in Jindo-gun, Jeollanam-do, Korea have beautiful nature and primordiality to such an extent that they are included in Dadohae National Marine Park. Basil Hall, a British naval officer and a traveller, visited China as the captain of Lyra, and stayed at Jodo Islands on his way to Ryukyu. Looking down Jodo islands at the top of Mt. Dori in Sangjodo Island, he expressed 'the ultimate of the world' at the time. Jodo islands are located in the south of Jindo Island and consist of 154 large and small islands. It was named Jodo (鳥島- birds-like islands) because it looked like a flying flock of birds. The largest island in the archipelago is about $7 \mathrm{~km}$ long, so the islands are literally a cluster of large and small grapes. These Jodo islands are very famous for their production of sea mustard. Especially, the wild sea mustard of Cheongdeungdo and Deokgeodo Islands is considered as the best quality among sea mustard gathered in Jindo Islands, so we can enjoy it only if we make a reservation before gathering.

“Augmented Survey of the Geography of Korea” (新增東國舆地勝覽) published in 1530 (the $25^{\text {th }}$ year of King Jungjon's reign) cited sea mustard as one of Jindo's indigenous products. Magazine of Jindo-gun published in 1923 recorded that the wild sea mustard gathered in Jindo islands was offered to the royal family and the royal court, and Dokgeo sea mustard out of them was considered as the best.

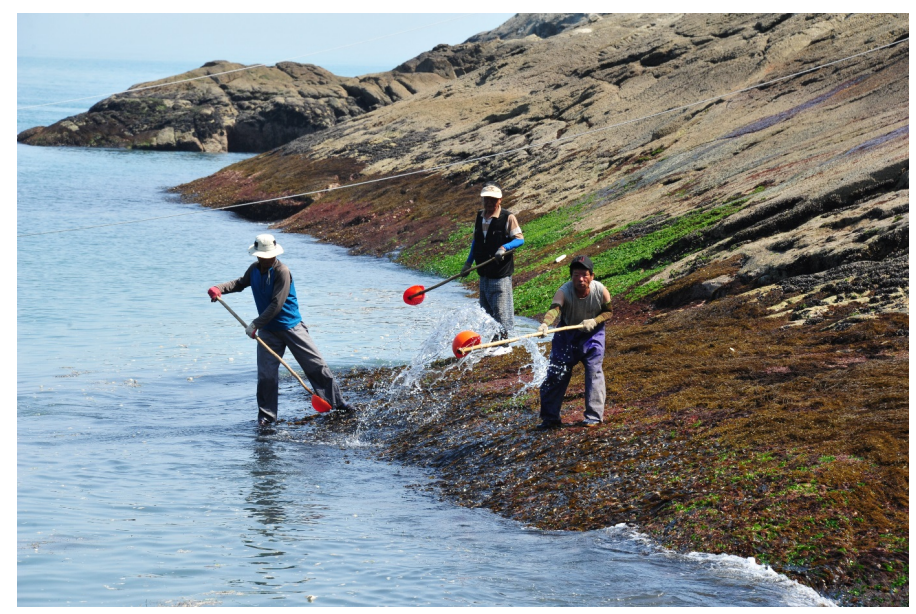

Fig 1. The mud-flat cleaning (seaweed removal) work on the sea-shore in Dokgeodo of Jodo Islands, Jindo for producing excellent quality of mustard area (photo: 9 June 2013, SK Hong).

Usually, the sea mustard has a characteristic that it is loosened as it is boiled, but the natural sea mustard gathered here is characterized by its sustainable color, elasticity and chewiness even if it is boiled for a long time. This wild sea mustard is known to be the best product for postnatal care soup, and has been reserved and sold entirely by some 
consumers. Even though the sea mustard has been recently mass-cultivated in Wando Island, the sea mustard in Jodo islands is widely known as luxury goods produced in a small quantity.

In Chungdeong Island and Deokgeodo Island, the islanders do the work of 'mudflat cleaning' (seaweed removal work) to wipe out rocks on the seashore from January to February every year so that spores of the wild sea mustard can be attached well. From December 15 to January 15 of the lunar calendar, the seaweed removal work is carried out in the field of the wild sea mustard. Since the wild sea mustard has been jointly produced by the village community, this work of 'mudflat cleaning' is also jointly carried out by the village community. In addition to 'mudflat cleaning', 'watering' to the mudflat is also done (Figure 1). By the time the mudflat cleaning results in the well attachment and growth of the beneficial sea algae spores such as sea weed fusiform and sea mustard, as the weather gets hot and dry, the young sea mustards die. Therefore, when the mudflat is exposed at the time of low tide, the sea water is pulled up and sprayed from time to time.

\section{Islandness}

There are expressions of "good-natured" and "heartedness". A person's character comes from his/her heart. The heart is an innate mind and interpreted as a true and unchanging noumenon of mind. There are 3,450 islands in our country. Raging from people with the surname entered into island hundreds of years ago to those with the surname entered into island recently, they have lived to form a variety of villages in the large and small, inhabited and uninhabited islands. Some islands have a population of about 200 with more than 25 surnames. Mostly, people with the surname entered into island first form the mainstream of the island society. In general, people who entered into the island afterwards set up their living base elsewhere. In other words, there are areas of their own surname. These areas are determined by the background and the mind of people with the same surname who entered into the island and formed village. If people entered into the island earlier are all-embracing, they will live together with those who entered subsequently. I have yet to see an island made up of only one surname. If any, it would be a very interesting subject to study islandness.

Some people say 'the island is closed', and others argue that 'it is open' because it is looking at the sea. Closedness and openness are two-sided characteristics of island, and such double-sidedness itself is an islandness. The island is both closed and open. In particular, such islandness is differentiated depending on what is surrounding the island. Is it a mudflat, another island or a long stretch of sea? The background of defining islands, including large or small islands, island adjacent to land and archipelagic islands, varies greatly depending on the island, sea and geopolitical role. However, the islandness is directly or indirectly influenced by the mind of residents. In other words, the sociality of those who have stepped on the island for the first time is also very relevant. As the saying goes 'the mind of village', every island has a different mind and emotion. Just as people have different genes, the combination of people forming the island society differentiates the features of islandness.

Sometimes, the islandness is over-determined by people living on the land. That is, it is the case where the mind trying to express in the heart of a person is expressed in response to the island. The expression on the island, which is mainly represented in works such as novels or poems, plays a role in fixing certain islandness. Even though some people had not lived on the island, they describe the island's secular life as if they had lived there for a long time. Therefore, if you say them, 'you've lived on this island!', there are many writers who can't make excuses. I think it's wrong to separate the 
island's closedness and openness from a dichotomous point of view. The islandness is not only determined by geographical features or spatial accessibility, but also by the mind of islanders.

As the island is closed, the islanders are not closed, and as the island is open to the sea, the islanders are not open. The island has very multifaceted characteristics and colors (Hong, 2019). It's just like an over-changing nature. Here, the minds of islanders will serve as an enzyme to mature the multifaceted islandness. I felt form the visit to and sightseeing of many islands around the world that the colors of the islands are different. In particular, although the islands are adjacent in distance, they often have distinct cultures and customs. Shinan-gun, Jeollanam-do, the only island-based administrative district in Korea, has recently been in the midst of a bridge project. The bridge connecting the adjacent islands and the bridge connecting the island and the inland will soon enable the islands to enter a one-day life zone (Hong, 2017b). Nevertheless, the island remains the island. The culture of various surnames, including surnames entered into the island first and their villages, are mixed in each island. In this way, the intermingling of genetic societies forms a single islandness in such a long period of time. I am concerned the bridge project will make this island-specific characteristic, namely the islandness, disappear (Hong, 2017).

\section{Sustainability}

Never before has interest in the island been heightened all over the world as it is today. The island is a territory, a biological resource and a place of life. Recently, ecosystems are changing drastically, ranging from the change of fish farms and the rise in sea levels due to global climate change to excessive development, marine pollution and natural disasters, and the small islands in the Asia-Pacific region are disappearing in the aspect of biodiversity as well as unique regional culture (Hong, 2017a). The international organizations such as IUCN, UNESCO and CBD are well aware of the interrelationships between biodiversity and cultural diversity on the island, and have already used the term 'bioculture' to conceptualize the characteristics of human life to adapt to various biological environments (Maffi, 2001), and the academia interprets and uses the term more broadly. (UNESCO Declaration on Cultural Diversity).

Sustainability of the island is possible when the island's environmental ecosystem, the 'biosphere', and the human social system, 'culture', coexist and balance. Yet, as in our country, there is still a very lack of discussion on the assessment and indicators for sustainability of islands in Asia-Pacific region (Campbell, 2009). Considering the urgent need to improve living conditions of island areas vulnerable to global climate change, including the rise in sea levels due to changes in marine climate, changes in farming and fishing base due to changes in the island's environment and natural disasters such as earthquake and tsunamis, it is required to implement ecosystem conservation for the coastal area, construction of infrastructure for islanders and qualitative economic system (Kim, 2013). It is necessary to conserve and utilize the unique biological and cultural resources possessed by Dadohae in West and South Sea, the representative island region in Korea, and to improve the life quality of islanders and to share their ecological values with people around the world.

Biocultural diversity is emerging in the dynamic process in which interactions between biological and cultural diversity and traditional knowledge work in a complex ecosystem (Maffi, 2001). Human beings have been using the surrounding landscape and creatures for a long time as living resources, and, if required, developed new species through cultivation (Kim, 2016). The use of biodiversity has served as a background for promoting cultural diversity such as food and residential culture, and this ecological knowledge has been spread to national levels beyond neighboring areas. In 
addition, local language and dialects are very vulnerable to Westernization and rapidly disappearing. The crisis of the indigenous knowledge on the use of natural resource can be regarded as a crisis of biodiversity driven by indiscreet energy development and land use.

I believe that the term 'biocultural diversity' was coined as a sign of coexistence between nature and human beings because biology and culture have different attributes, but are under a fateful dependency relationship that human beings have been repeatedly developed to depend on nature and cannot exist without the use of natural resources. In this way, it is undeniable that human beings and nature have been interdependent, contacted and supplemented in the ecosystem, but it is necessary for the government, researchers, citizens and experts to deeply understand that the connection point is declining due to the rapidly changing global environment, reckless development and the reduced biodiversity.

\section{Island Industry and Future Technology}

With the world's great interest and investment in the Fourth Industrial Revolution, the public pledges on the Fourth Industrial Revolution are heating up among the presidential candidates in our country. However, this will have our head in the clouds if we cannot correctly understand the characteristics and world dominance of the Fourth Industrial Revolution. The information technology, that is, internet has already developed rapidly throughout the third industrial revolution. The internet network speed is only different, but it becomes an opportunity for the world to get closer quickly. Now, most of the industrial bases, including financial market all over the world, are working within the global internet network. But, notebooks or mobile phones have been used for the existing internet, and from now won, any surrounding electronic appliances will be available as internet-enabled media. That's "IoT (Internet of Things)" technology. In other words, a revolutionary change in manufacturing and daily life takes place due to all products and things available at internet network.

Each country's move in response to the Fourth Industrial Revolution is very rapid, especially Japan having a solid foundation of small and medium manufacturing is moving toward an interesting direction. Lee Teng-hui, the president of the Republic of China, visited Ishigaki Island, Okinawa, and suggested mutual cooperation between Taiwan and Ishigaki Island in connection with the Fourth Industrial Revolution at the lecture for the island's youth council. Along with Iriomote Island, Ishigaki Island belongs to Okinawa, and a tourist spot where coral reefs, mangrove vegetation and unique island culture are well preserved. Further, its marine ecosystem is very great to such an extent as the Japanese government has prepared to put emphasis on being designated as a UNESCO World Heritage Site. Ishigaki Island has been interacting with Taiwan for a long time, For example, it is said that the prototype of a water buffalo on Ishigaki Island came from Taiwan, and workers from Taiwan, formerly Japanese colony, moved to Okinawa and were used as a labor force when they were mobilized for pineapple farms and rice cultivation. I believe there is this kind of historical basis for the expression of industrious Taiwanese as "water buffalo spirit" because a water buffalo worked at a labor force equivalent to 4 to 5 persons. Even after World War II, the Taiwanese farming businesses continued in the devastated Okinawa, especially, they recovered the past pineapple farms and activated the secondary industry, the canned food processing. These Japanese and Taiwanese capital and technology are working together to generate a new industry on the island. They say that all pineapple farms will be transformed into the remote high-tech farms equipped with internet systems so 
that all management, production and processing can be directly done in Taiwan. Production site is Ishigaki Island, but producers and managers are Taiwanese.

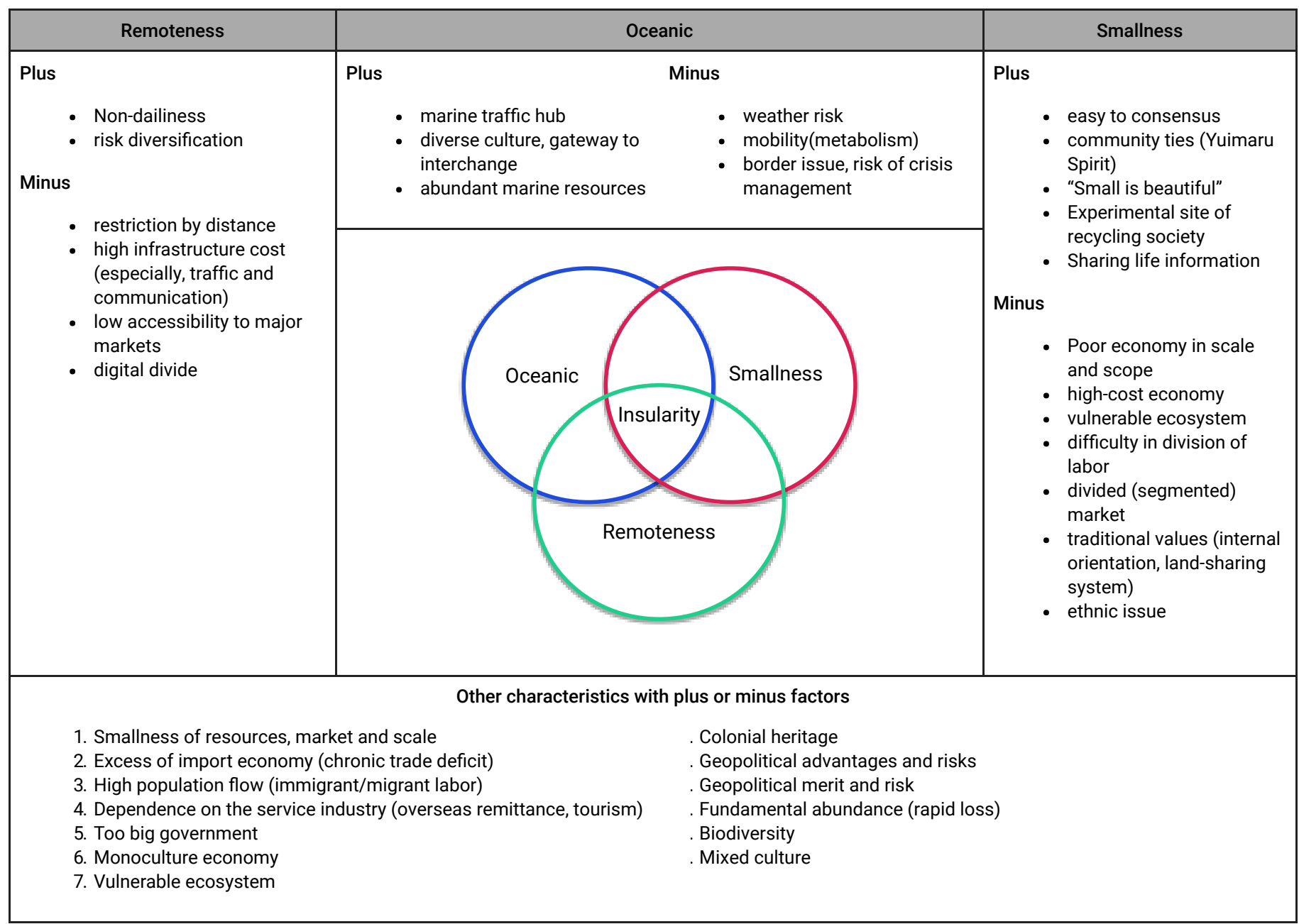

Fig 2. Key characteristics of island region from the viewpoint of economic development theory (Redrawing original figure prepared by Kakazu Hiroshi, 2019)

Figure 2 is a case-by-case summary on the key characteristics of the island region from the viewpoint of economic development theory (Kakazu, 2019 from Kakazu, 1994). The table presents the positive assessment and negative effects on economic activation influenced by the typical features of the world islands, 'oceanic, smallness and remoteness'. For example, the oceanic creates an irregular environment depending on the marine climate, and decreases the quality of life, but on the other hand, enables to have abundant marine resources due to the influence of ocean currents and sea winds, which has a positive effect on eco-tourism or cross-cultural exchanges (Royle, 2001).

Then, is the 'Internet of Things' applicable to the island industry? The representative industries in Korean islands are mainly fishing and agriculture. The proportion of primary industries is so high to such an extent that the islanders almost engage in agriculture and fishery concurrently (Kim, 2016). Especially, fishery remains in the primary industry 
(production) such as cultivation of abalone, sea cucumber, other fishes and shellfish, and laver and other marine algae. In order for the island to be economically viable and rejuvenated, it is very important to revitalize the island's traditional industries and increase their self-sufficiency. If the various aquaculture industries remaining in the primary industry will be leveled up to the secondary (processing) industry, the international competitiveness of our marine fisheries industry will grow rapidly, and thus the economic power of the islands region will increase. If manufacturing industry that incorporates "Internet of Things" technology can be introduced into the secondary industrialization process of the island region where is currently under rapid aging and depopulation, it will be very helpful for activating the fishing community. One of the most interesting things in the Fourth Industrial Revolution is the remarkable development of manufacturing by the role of robots and Al. Since most of the islands in Korea are adjacent to inland metropolises, only if accessible, they can be sufficiently spotlighted as a space for recreation and settlement. If we introduce the silver industry of the aging Korean society to the island, and link the robot and Al to the silver industry and island tourism infrastructure, I believe that the island has attractive location as a clean residential area as well as a space for production.

\section{Conclusion: Understanding an island by the multidisciplinary approach}

An island is like a living organism where biocultural diversity and ecosystems interact. The marine history of human beings confirms that the island's culture depends on natural resources, and is repeatedly created and disappears. The ecosystem prototype of the current island areas is threatened by rapid changes in climate and marine environment, instability in natural disasters, alienation of residents due to tourist attractions and reckless development of resources (Hong G, 2018).

\begin{tabular}{|l|l|}
\hline \multicolumn{1}{|c|}{ Classification } & \multicolumn{1}{c|}{ Implementing Factors } \\
\hline $\begin{array}{l}\text { Environmental } \\
\text { Healthiness }\end{array}$ & $\begin{array}{l}\text { ecosystem, natural landscape, environmental quality, environmental improvement closely related to everyday life, counteraction against } \\
\text { climate change, low carbon-based environment (resource saving), open space, etc. }\end{array}$ \\
\hline $\begin{array}{l}\text { Economic } \\
\text { Activation }\end{array}$ & job creation, income increase, expansion of local industrial base, creation of tourism infrastructure, etc. \\
\hline $\begin{array}{l}\text { Cultural } \\
\text { Uniqueness }\end{array}$ & artificial landscape, design, region's unique tradition, folklore and customs, the islander's cultural capabilities \\
\hline Social Equity & $\begin{array}{l}\text { use of and accessibility to urban infrastructure, consideration of the disadvantaged, social safety (security, traffic), health care (public } \\
\text { health and hygiene), provision of educational opportunity }\end{array}$ \\
\hline
\end{tabular}

The island is also a region where the complex multi-layered issues of environment/society/ economy are rapidly increasing, including uncertainty of economic growth path, low growth and low consumption, rapid depopulation and aging, and uninhabited situation (Hong et al., 2018). In order to maintain sustainability of the earth, the three pillars of the environmental, social and economic system must be complementary to each other to achieve balanced development while maintaining each other's boundaries. However, the current unbalanced use of global resources is causing a host of environmental and social problems such as overfishing and pollution. In particular, for islands with limited areas and 
resources under a special environment surrounded by the sea, the unpredictable uncertainties in many aspects play a trigger role for major environmental changes (Caldeira and Wickett, 2003). The island and marine society that is undergoing the rise in sea level and sea temperature, and changes in fishing farm and marine ecosystems is in need of confrontational policies on sustainability that is different from the existing continental environment (Botsford, 1997).

As we go into the $21^{\text {st }}$ century, the international community has set up UN's MDGs (Millennium Development Goals), proposing specific indicators for pursuing common prosperity of mankind and calling for efforts of each country (Hong et al., 2017). MDGs has the meaning to reach a global consensus with the participation of international organizations, NGOs and other various entities, but has been assessed to have insufficient effectiveness or performance as it has set the agenda in the UN-centered top-down manner, focusing on the pending issues centered on the developing countries. Especially, the global environmental issues are not unique to developing countries, and despite the fact that the source of important environmental problems is due to the excessive growth strategy of developed countries, it is difficult to establish a global cooperative system between development and developed countries. Sustainable Development Goals (SDGs) was implemented by the convergence and agreement that the 2012 Rio+20 meeting drew in relation to the situation requested by the goal of international society in order to achieve sustainable development after 2015 . With respect to the goal of sustainable development, the implementation period is for 15 years from 2016 to 2030 , and 17 goals proposed at the UN General Assembly in September 2015 have been adopted and become effective from 2016. The 17 goals are broadly classified into five categories: poverty eradication, social development, economic development, environmental conservation and implementation cooperation. In addition, a detailed target has been set for each goal, with a total of 169 detailed targets being pursued. As such, the UN has proposed sustainable development goal (SDG) strategy for the sustainable social development, and countries around the world are setting direction of their national policies in line with this global indicator (Ro, 2014).

The island is a special space where nature and humans use marine resources to live in a limited space surrounded by the sea, so it is very difficult to combine sustainability assessments applicable to inland (Royle, 2001). The island has a double-sided feature of isolation and communication due to its ecological features surrounded by the sea on four sides (Table 2). Furthermore, determining the island's cultural identity is an ecological geographical feature of the sea surrounding the island (Hong, 2011b). whether the island is closed or open, the sea is dirty or clear, the coast is mudflat, sand or gravel, the sea is distant or close, archipelago, a sole island or an island connecting to the land....it is all physical, but the traditional ecological knowledge of the islanders who recognize it and leads their lives determines the culture and identity of the island (Hong G., 2018).

It is not easy to investigate, analyze and assess sustainability of these islands (Kakazu, 2019). It is likely that the new evaluation index should be prepared by means of mutual cooperation and check between evaluation items in various files from a multidisciplinary viewpoint (Nakagoshi and Hong, 2001, Hong, 2007, Baldacchino, 2019). As one option, the concept of biocultural diversity may be used for the development of evaluation method on the island sustainability. To this end, it is required for open awareness on how to create flexibility and network to understand and study the island diversely, beyond the disciplinary boundaries of the humanities, social science and natural science (Hong et al., 2018). 


\section{Acknowledgements}

This research was conducted with the support of National Research Foundation of Korea (NRF-2009-361-A00007) funded by Korean government (Ministry of Education, Science and Technology) in 2009.

\section{References}

Baldacchino, G., 2019. How far can one go? How distance matters in island development. Island Studies Journal (in press)

Botsford, L.W., Castilla, J.C., Peterson, C.H., 1997. The Management of Fisheries and Marine Ecosystems. Science 277: 509-515.

DOI:10.1126/science.277.5325.509

Caldeira, K., Wickett, M.E., 2003. Anthropogenic carbon and ocean pH. Nature 425(6956): 365-365.

Campbell J., 2009. Islandness-Vulnerability and Resilience in Oceania. Shima 3(1): 85-97.

Grydehøj, A. 2015. Island city formation and urban island studies. Area 47(4): 429-435. https://doi.org/10.1111/area.12207

Hatakeyama, S. 2006. The Forest is the Ocean's Sweetheart (森は海の恋人). Bunshunbunko, Tokyo (In Japanese)

Hong, G., 2018. Islands of enclavisation: Eco-cultural island tourism and the relational geographies of near-shore islands. Area 50: 1 9.

Hong, S.K., 2019. Biocultural Diversity and Ecological Values of Island and Coast- Suggestions for Sustainable Development. Minsokwon, Seoul. (In Korean)

Hong, S.K., Won, Y.T., Lee, G.A., Han, E.S., Cho, M.R., Park, H.Y., Kim, J.E., Chisholm Hatfield, S., 2018. Interdisciplinary Convergence Research Design on Island Biocultural Diversity-Case Study in Wando-gun (County) Island Region, South Korea. Journal of Marine and Island Cultures, 7(1): 12-37.

Hong, S.K., 2017. Bridge and Islandscape: Questions for sustainability and resilience of island societies in Korea and Japan, in: S.K. Hong, N. Nakagoshi (Eds.), Landscape Ecology for Sustainable Society. Springer. (https://doi.org/10.1007/978-3-319-74328-8_22)

Hong, S.K. J.E. Kim, T. H. Ro, 2017. Island Biocultural Diversity Initiative for Sustainable Society in Asia-Pacific Island Regions, in: S.K. Hong and N. Nakagoshi (Eds.), Landscape Ecology for Sustainable Society. Springer. (https://doi.org/10.1007/978-3-319-74328-8_2)

Hong, S.K., J. Bogaert, Q. Min, 2014. Biocultural Landscapes-Diversity, Functions and Values. Springer-Verlag, Dordrecht.

Hong, S.K., 2011a. Biocultural diversity and traditional ecological knowledge in island regions of Southwestern Korea. J. Ecol. Field. Biol. 34(2): 137 147 (DOI:10.5141/JEFB.2011.026).

Hong, S.K., 2011b. Eco-cultural diversity in island and coastal landscapes: conservation and development, in: Hong, S.K., Wu, J., Kim, J.E., Nakagoshi, N. (Eds.), Landscape ecology in Asian cultures, Springer, Tokyo, pp.11-28.

Hong, S.K., 2010. Biocultural diversity and traditional ecological knowledge in island regions of Southwestern Korea. J. Ecol. Field. Biol. 34(2): 137-147.

Hong, S.K., 2007. Linking man and nature landscape systems: landscaping Blue-Green network, in: Hong, S.K., Nakagoshi, N., Fu, B., Morimoto, Y. (Eds.), Landscape ecological applications in man influenced areas: linking man and nature systems, Springer, Dordrecht, pp.505-523.

Hong, S.K., Kim, J.E., 2007. Circulation and network of forest-stream-coastal ecosystems. Island Cult 30: 267-286. 
Huston, M., 2014. Disturbance, productivity, and species diversity: empiricism vs. logic in ecological theory, Ecology 95(9): 2382-2396.

Kakazu, H., 2019. Nissology. Kokon-Shoin Publishers, Tokyo. (In Japanese)

Kakazu, H., 1994. Sustainable Development, of Small Island Economies, Boulder: Westview Press.

Kelman, I., 2006. Island security and disaster diplomacy in the context of climate change, Les Cahiers de, la Sécurité 63: 61-94.

Kim, J.E., 2013. Sustainable maritime and island policy in the national territory. Isl. Cult. 41:305-327 (In Korean)

Kim, J.E., 2016. Land use patterns and landscape structures on the islands in Jeonnam Province's Shinan County occasioned by the construction of mainland bridges. J. Mar. Isl. Cult. 5:53-59.

Maffi, L., 2001. On Biocultural Diversity. Linking Language, Knowledge and the Environment, Washington \& London: Smithsonian Institution Press.

Nakagoshi, N., S.K. Hong, 2001. Vegetation and Landscape Ecology of East Asian 'SATOYAMA'", Global Environ. Res. 5(2): $171-181$.

Rapport, D. J., 2006. Sustainability science: An eco-health perspective, Sustainability Science 2: 77-84.

Ro, T.H., 2014. The trends of the discussions of the SDG's system of the UN and the domestic coping plan. The symposium of the National Assembly 'The future tasks for the re-establishment of the sustainable development system of the country and the leap' (Dec. 2014)

Royle, S.A., 2001. A Geography of Islands: Small Island, Insularity, London, Routledge.

Shim, J.B., 2015. Island characteristics and tourism policy tasks. Report from Incheon City Island Tourism Promotion Forum (March 2015).

UNESCO Declaration on Cultural Diversity. http://unesdoc.unesco.org/images/0012/001271/127160m.pdflink 